\title{
ADAPTASI PERILAKU PETANI PADI DAERAH PINGGIRAN KOTA DI ERA COVID-19 SERTA PENGARUHNYA TERHADAP USAHATANI (Studi Kasus: Desa Sukabakti, Kecamatan Tambelang, Kabupaten Bekasi)
}

\section{ADAPTATION OF SUBURBAN RICE FARMERS BEHAVIOR IN THE COVID-19 ERA AND ITS EFFECT ON FARMING (Case Study: Sukabakti Village, Tambelang District, Bekasi Regency)}

\author{
Yomitha Faradina*, Yayat Sukayat \\ Program Studi Agribisnis, Fakultas Pertanian, Universitas Padjadjaran \\ *Email: yomitha17001@mail.unpad.ac.id \\ (Diterima 23-02-2021; Disetujui 03-06-2021)
}

\begin{abstract}
ABSTRAK
Covid-19 berdampak terhadap sektor pertanian dan petani sehingga berpengaruh terhadap proses budidaya, pemasaran serta pendapatan mereka, sehingga mengubah perilaku petani untuk tetap bertahan hidup dan mempertahankan ketersediaan pangan pokok. Tujuan penelitian adalah untuk mengetahui karakteristik petani padi dan menganalisis adaptasi perilaku petani daerah pinggiran kota serta pengaruhnya terhadap usahatani selama pandemi Covid-19. Penelitian ini menggunakan metode kualitatif dengan pendekatan studi kasus di Desa Sukabakti, Kabupaten Bekasi. Penentuan informan dilakukan menggunakan metode snowball sampling. Hasil dari penelitian menunjukkan pandemi covid-19 memberikan pengaruh terhadap petani padi daerah pinggiran kota Bekasi dan Jakarta. Dalam usahatani padi petani mengalami pengaruh cukup besar pada penjualan gabah, tenaga kerja dan penyaluran pupuk subsidi, yang disebabkan kurangnya pengetahuan petani dalam memasarkan gabah sehingga petani kesulitan dan sering mengalami kerugian akibat gabah yang dihargai cukup rendah. Berdasarkan pengaruh tersebut petani melakukan beberapa adaptasi sehingga dapat terus bertahan hidup selama Covid-19. Adaptasi yang dilakukan yaitu pengurangan tenaga kerja buruh menjadi tenaga kerja keluarga, pengurangan penjualan pada gabah padi, melakukan pekerjaan sampingan sebagai pedagang, pengurangan pemberian dosis pupuk, menerima bantuan dari pemerintah.
\end{abstract}

Kata kunci: Usahatani, Covid-19, Petani Padi, Adaptasi

\section{ABSTRACT}

Covid-19 has an impact on the agricultural sector and farmers so that it affects their cultivation, marketing and income processes, thereby changing farmers' behaviour to survive and maintain the availability of staple food. The purpose of this study is to find out the characteristics of rice farmers and analyse the adaptation of suburban farmers' behaviour and their influence on farming during the Covid-19 pandemic. This research is using qualitative research with a case study approach at Sukabakti Village, Bekasi Regency. The sample selection using snowball sampling method. The results of study showed that the Covid-19 pandemic has an influence on rice farmers in the suburbs of Bekasi and Jakarta. In rice farming farmers have a considerable influence on grain sales, labor and distribution of fertilizer subsidies, caused by the lack of knowledge of farmers in marketing grain so that farmers are difficult and often suffer losses due to grain that is valued quite low. Based on this influence, farmers make several adaptations so that they can to survive during Covid-19. Adaptations are reduction of labor into family labor, reduction of sales on rice grain, doing side work as traders, reduction of fertilizer dose, receiving government support.

Keywords: Farming, Covid-19, Rice Farmers, Adaptation 


\section{PENDAHULUAN}

Indonesia merupakan salah satu negara konsumen beras terbesar di dunia, bahkan menempatkannya sebagai makanan pokok. Berdasarkan data BPS Indonesia tahun 2019, penduduk Indonesia mengkonsumsi beras sekitar 111,58 per kapita per tahun. Sehingga secara nasional kebutuhannya mencapai 31,31 juta ton.

Pertanian bagi Indonesia merupakan sektor yang penting dan berpengaruh baik secara ekonomi, sosial serta politik disebabkan terkait pada penyediaan kebutuhan pangan pokok terutama pada komoditas padi sebagai komoditas pangan utama (Muttaqin, 2008). Pertumbuhan penduduk yang semakin meningkat $1,25 \%$ pert ahun (BPS, 2019), peningkatan produksi menjadi suatu keharusan agar produksi padi dapat menunjang permintaan pangan yang tinggi.

Data BPS (2019) menunjukkan bahwa produksi padi pada tahun 2019 sebesar 54,60 juta ton Gabah Kering Giling (GKG) atau mengalami penurunan sebesar 4,60 juta ton $(7,76 \%)$ dibandingkan dengan tahun sebelumnya pada 2018.

Jawa Barat merupakan salah satu sentra produksi padi di Indonesia yang memberikan kontribusi besar terhadap produksi beras nasional, yaitu sekitar $16 \%$ terhadap produksi padi nasional (Dinas Pertanian Tanaman Pangan Jawa Barat, 2019). Salah satu sentra produksi padi di Jawa Barat berada di Kabupaten Bekasi yang merupakan sentra produksi padi dengan produksi tertinggi pada tahun 2016 yaitu 611.386 ton dan produksi terendah terjadi pada tahun 2014 yaitu 516.898 ton (BPS, 2018). Kabupaten Bekasi dikenal sejak lama sebagai salah satu daerah penghasil padi di Jawa Barat yang dapat memenuhi kebutuhan pangan, bukan hanya untuk wilayahnya saja, melainkan juga dapat memenuhi kebutuhan beras di daerah sekitarnya seperti DKI Jakarta, Jawa Tengah dan Jawa Timur. Dari tahun ke tahun produktivitas padi di Kabupaten Bekasi kini mengalami penurunan yang disebabkan oleh adanya peralihan fungsi lahan persawahan menjadi kawasan industri, pemukiman, tata pengelolaan pertanian serta adanya perubahan iklim (Boer et al, 2013).

Produksi padi di Kecamatan Tambelang mengalami peningkatan dengan rata-rata produksi 48.439 ton pertahun (BPS, 2018). Kendatipun kecamatan ini merupakan kecamatan yang berbatasan/penyangga provinsi 
DKI, namun produksi padinya masuk dalam 3 besar di Kabupaten Bekasi setelah Pebayuran dan Sukakarya, walaupun saat ini sedang mengalami penurunan produksi dan produktivitas padi akibat adanya alih fungsi lahan persawahan menjadi kawasan industri serta pemukiman, banyak saluran air yang tidak berfungsi.

Pada Maret 2020, World Health Organization mengumumkan bahwa Covid-19 menjadi pandemi. Kemunculan wabah virus jenis baru ini telah menggemparkan seluruh dunia. Virus Covid-19 merupakan penyakit menular dengan gejala flu, demam hingga gangguan pernafasan, yang penyebarannya melalui tetesan air liur dari batuk dan bersin oleh seseorang yang terkena penyakit (WHO, 2020). Efek pandemi Covid-19 telah mempengaruhi seluruh elemen pada sistem pangan, mulai dari pasokan utama atau produksi, pemrosesan, perdagangan secara nasional dan internasional, sistem logistik dan permintaan di tahap menengah dan akhir (FAO, 2020). Kondisi tersebut telah menekan pertumbuhan ekonomi dan menimbulkan dampak sosial khususnya pada sektor pertanian. Adanya pembatasan distribusi dan pergerakan serta aktivitas pada masyarakat bertujuan untuk memutus rantai penyebaran Covid19. Pandemi Covid-19 di Indonesia berdampak besar pada sektor pertanian, yaitu memiliki peluang bagi sektor pertanian dalam memenuhi kebutuhan pangan masyarakat. Namun, pada kenyataannya terdapat beberapa kendala yaitu petani harus beradaptasi dengan perilaku yang baru dengan mematuhi dan taat pada protokol pemerintah untuk menjaga jarak, menggunakan masker, mencuci tangan dan tidak melakukan kerumunan sehingga mempengaruhi aktivitas petani dalam kegiatan berusahatani.

Dampak pandemi Covid-19 ini sangat terasa oleh warga masyarakat yang tempat tinggalnya berbatasan dengan Provinsi DKI seperti Kecamatan Tambelang, khususnya Desa Sukabakti. Secara umum, Desa Sukabakti memiliki lahan pertanian sawah paling luas di Kecamatan Tambelang. Desa Sukabakti merupakan salah satu desa yang berada di Kecamatan Tambelang, Kabupaten Belasi, Jawa Barat dengan luas areal persawahan terluas se-kecamatan Tambelang, yaitu seluas $5,60 \mathrm{~km}^{2}$. Secara demografis, penduduk di Desa Sukabakti mayoritas adalah petani dan buruh tani sebagai mata pencahariannya dengan 


\section{ADAPTASI PERILAKU PETANI PADI DAERAH PINGGIRAN KOTA DI ERA COVID-19 \\ SERTA PENGARUHNYA TERHADAP USAHATANI \\ Yomitha Faradina, Yayat Sukayat}

status kepemilikan lahan yang didominasi oleh lahan sewa (Data Profil Desa, 2019).

Menurut data profil desa tahun 2019, 46,91\% masyarakat Desa Sukabakti berprofesi sebagai petani dan buruh tani yang berstatus kepemilikan lahan yaitu lahan sewa dengan kategori terbanyak. Hal tersebut membuktikan bahwa pertanian masih menjadi sumber utama dalam pergerakan ekonomi di Desa Sukabakti. Penelitian dilakukan di Desa Sukabakti karena ingin mengetahui apakah timbulnya pandemi Covid-19 berdampak pada perilaku petani dan pengaruhnya terhadap kegiatan usahatani padi serta bagaimana karakteristik petani padi di Desa Sukabakti yang merupakan wilayah penyangga/berbatasan yang selama masa pandemi segala aktivitas serba dibatasi dengan berlakunya Pembatasan Sosial Berskala Besar (PSBB) dan Pemberlakuan Pembatasan Kegiatan Masyarakat (PPKM), akibat Kabupaten Bekasi yang merupakan salah satu wilayah dengan zona merah.

\section{METODE PENELITIAN}

Penelitian ini merupakan penelitian deskriptif kualitatif dengan pendekatan studi kasus, dengan fokus penelitian yaitu adaptasi perilaku petani padi daerah pinggiran kota serta pengaruhnya pada kegiatan usahatani selama pandemi Covid-19, dengan objek penelitian yang merupakan lima petani padi, satu ketua kelompok tani serta satu kepala desa dengan lima diantaranya memiliki pekerjaan sampingan sebagai pedagang dan dua sisanya menjadikan pertanian sebagai mata pencaharian utama. Penentuan informan dilakukan dengan cara snowball sampling. Dimana menurut Nurdian (2014), snowball sampling adalah suatu metode yang digunakan untuk mengidentifikasi, memilih dan mengambil sampel dalam suatu jaringan atau rantai hubungan yang menerus. Teknik pengumpulan data dilakukan dengan melakukan wawancara secara langsung, observasi dan dokumentasi sesuai preferensi petani padi dan juga studi literatur yang terkait dengan penelitian. Penelitian ini dilaksanakan pada bulan Desember 2020 sampai Januari 2021 dengan penentuan lokasi yang dilakukan sengaja dengan mempertimbangan bahwa Desa Sukabakti merupakan salah satu sentra produksi padi di Kabupaten Bekasi, Jawa Barat, yang juga berada di daerah pinggiran Kota Bekasi dan DKI Jakarta, dan masih memiliki lahan pertanian walaupun telah dipenetrasi budaya kota dan banyaknya industri serta pemukiman. 
Data sekunder diperoleh dari buku-buku, jurnal dan skripsi, internet serta data yang didapatkan dari suatu lembaga yang berhubungan dengan kondisi masyarakat di Desa Sukabakti.

Teknik analisis data yang digunakan pada penelitian ini adalah reduksi data, penyajian data dan penarikan kesimpulan.

\section{HASIL DAN PEMBAHASAN}

\section{Gambaran Umum Desa Sukabakti}

Desa Sukabakti merupakan salah satu desa yang memiliki luas sawah terluas se-kecamatan Tambelang. Desa Sukabakti memiliki luas total wilayah tahun 2018 yaitu 859.096 Hektar yang terbagi dalam dua bagian, yaitu luas sawah seluas 749.024 ha dan luas daratan seluas 110.075 ha. Desa Sukabakti memiliki jarak tempuh 3-4 km ke kantor desa dan $15 \mathrm{~km}$ ke pusat kota (Data Profil Desa, 2019).

Desa Sukabakti terdiri atas 6 RW dan 12 RT. Desa Sukabakti memiliki jumlah penduduk sebanyak 8.019 jiwa dengan proporsi jumlah laki-laki sebanyak 4.015 jiwa dan perempuan berjumlah 4.005 jiwa. Jumlah total penduduk seluruhnya terbagi dalam 1.857 Kepala Keluarga yang tersebar dalam tiga wilayah dusun (Data Profil Desa, 2019).

\section{Karakteristik Petani Padi di Desa Sukabakti}

\section{a. Kelompok Usia Petani}

Kelompok usia petani berdasarkan jumlah petani dalam kelompok tani di Desa Sukabakti. Data jumlah petani berdasarkan usia bermanfaat untuk mengetahui jumlah angkatan kerja yang ada. Data jumlah petani menurut kelompok usia di Desa Sukabakti dapat dilihat pada Tabel 1.

Tabel 1. Kelompok Usia Petani

\begin{tabular}{cccc}
\hline No. & $\begin{array}{c}\text { Kelompok } \\
\text { Umur }\end{array}$ & \multicolumn{2}{c}{ Desa Subabakti } \\
\hline & Petani & Frekuensi & Persentase \\
\hline 1. & $<40$ & 4 & $10 \%$ \\
\hline 2. & $40-49$ & 11 & $27,50 \%$ \\
\hline 3. & $50-59$ & 19 & $47,50 \%$ \\
\hline 4. & $>59$ & 6 & $15 \%$ \\
\hline & Jumlah & 40 & $100 \%$ \\
\hline
\end{tabular}

Sumber: Data Profil Desa, 2018

Berdasarkan Tabel 1, dapat diketahui bahwa total jumlah petani pada kelompok tani di Desa Sukabakti yaitu sebanyak 40 orang. Pada usia produktif dengan kategori terbanyak yaitu pada usia 50-59 sebanyak 19 orang $(47,50 \%)$ dan kategori rendah pada usia $<40$ sebanyak 4 orang (10\%). Hal ini menunjukkan bahwa petani padi pada kelompok tani di Desa Sukabakti, generasi muda masih sangat minim dalam minat untuk bertani dan bergelut pada pertanian. Sehingga banyak petani dengan usia lanjut yang melakukan usahatani tersebut. 
b. Jenis Kelamin Petani Berdasarkan

\section{Kelompok Tani}

Ditinjau dari jenis kelamin petani di Desa Sukabakti yang didominasi oleh petani yang berjenis kelamin laki-laki dengan rincian data pada Gambar 1.

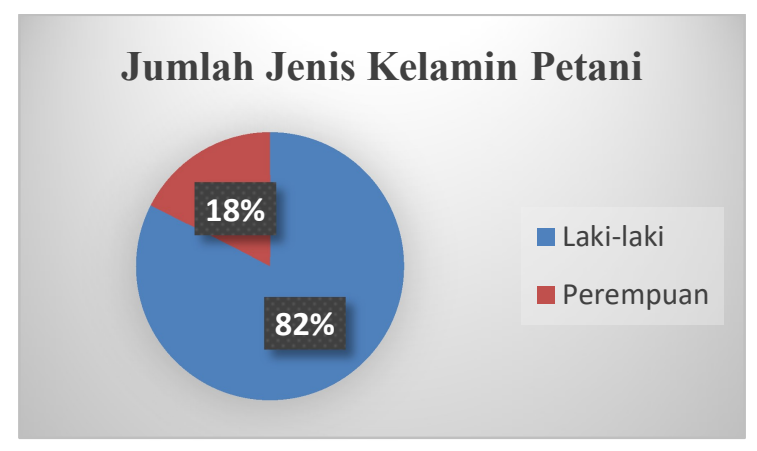

Gambar 1. Diagram Jenis Kelamin Petani Desa Sukabakti Tahun 2018 Sumber: Data Profil Desa, 2018

Berdasarkan Gambar 1, dapat diketahui bahwa jumlah petani berdasarkan kelompok tani sebanyak 40 orang, didominasi oleh petani dengan jenis kelamin laki-laki sebanyak 33 orang (82\%). 7 orang sisanya adalah perempuan yang hanya sebagai tenaga tambahan dalam pengelolaan usahatani padi.

\section{c. Tingkat Pendidikan Petani Berdasarkan Kelompok Tani}

Tingkat pendidikan berpengaruh terhadap kualitas sumber daya manusia, dimana proses pembangunannya akan berjalan lancar jika petani memiliki tingkat pendidikan yang tinggi. Tingkat pendidikan petani dapat diketahui pada Gambar 2.

\section{Tingkat Pendidikan Petani}

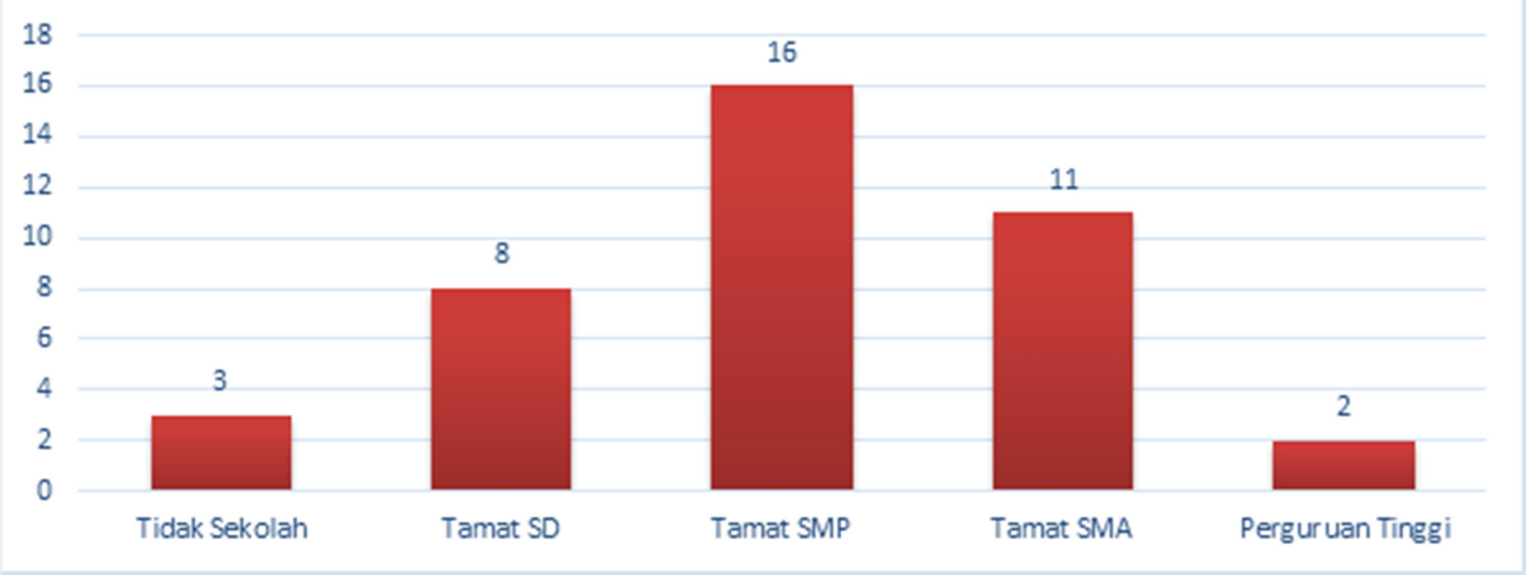

Sumber: Data Profil Desa, 2019

Gambar 2. Tingkat Pendidikan Petani Berdasarkan Kelompok Tani di Desa Sukabakti

Berdasarkan pada Gambar 2 dapat diketahui bahwa tingkat pendidikan petani dalam kelompok tani di Desa Sukabakti tingkat pendidikan tertinggi yaitu pada petani tamatan SMP berjumlah 16 orang dengan persentase $40 \%$ dan tingkat kategori rendah pada pendidikan petani yaitu pada tingkat pendidikan 
perguruan tinggi berjumlah 2 orang dengan persentase $5 \%$ dari total jumlah petani 40 orang. Petani didominasi oleh tamatan SMP sehingga minim sekali ilmu yang dimiliki terkait pertanian. Oleh sebab itu, rata-rata petani di Desa Sukabakti belajar secara otodidak serta berdasarkan pada ilmu yang berasal dari kegiatan penyuluhan yang dilatih melalui Dinas Pertanian Kabupaten Bekasi (Data Profil Desa, 2018).

\section{d. Status dan Luas Kepemilikan Lahan Kelompok Tani}

Berdasarkan wawancara langsung kepada petani dan ketua kelompok tani di Desa Sukabakti, Status dan Luas Kepemilikan Lahan yang digunakan oleh petani dan kelompok tani di Desa Sukabakti umumnya dibedakan atas dua, yaitu lahan milik sendiri dan lahan sewa. Mayoritas penggunaan lahan didominasi oleh lahan sewa yang petani sewa kepada pemilik lahan. Luas kepemilikan lahan petani sekitar 0,5 hingga 4 hektar.

\section{Kondisi Petani Padi Daerah Pinggiran Kota di Desa Sukabakti Selama Covid- 19}

Berdasarkan penelitian di lapangan, umumnya petani mengenali virus Covid19 berdasarkan himbauan yang berasal dari Aparat Desa Sukabakti yang memberikan pengumuman secara berkeliling desa serta himbauan dari pemerintah yang berada di televisi. Selama pandemi petani tetap melakukan aktivitas bertani untuk memproduksi padi agar tetap menjaga ketersediaan bahan pangan pokok dalam memenuhi kebutuhan keluarga petani serta masyarakat di sekitarnya. Sementara produksi padi yang tetap berjalan, petani tetap mematuhi himbauan dari pemerintah untuk menjaga jarak, memakai masker dan tidak melakukan kerumunan. Sebab, diketahui petani di Desa Sukabakti didominasi oleh petani dengan usia 40 sampai 50 tahun ke atas. Dimana menurut World Health Organization (2020), lansia dengan usia 50 tahun ke atas akan lebih rentan mengalami infeksi virus Covid-19, dan kematian dibandingkan pada balita yang disebabkan menurunnya daya tahan tubuh, sehingga petani saat ini lebih berhati-hati dalam melakukan kegiatan bertani.

Selama pandemi Covid-19, waktu bekerja petani tidak mengalami perubahan dan tetap bekerja pada pukul 6 pagi hingga 4 sore. Hal imi dilakukan agar produksi padi tetap berjalan dengan baik dan memiliki hasil yang optimal. Tidak adanya perubahan waktu petani dalam bekerja, hadirnya Covid-19 petani 


\section{ADAPTASI PERILAKU PETANI PADI DAERAH PINGGIRAN KOTA DI ERA COVID-19 \\ SERTA PENGARUHNYA TERHADAP USAHATANI \\ Yomitha Faradina, Yayat Sukayat}

mengalami kerugian akibat harga gabah yang petani jual kepada tengkulak menurun, Sehingga berpengaruh terhadap total pendapatan mereka.

Hasil penelitian terhadap lima petani, satu ketua kelompok tani dan satu kepala desa mengkonfirmasi bahwa pandemi Covid-19 mempengaruhi aktivitas petani. Perubahan yang paling dirasakan yaitu ketika diumumkannya PSBB oleh pemerintah pusat sehingga berdampak pada petani dengan dikeluarkannya himbauan pembatasan dalam melakukan aktivitas di luar rumah oleh aparat desa.

\section{Pengaruh Covid-19 Terhadap Usahatani Padi di Desa Sukabakti}

\section{a. Lahan}

Berdasarkan hasil penelitian, status kepemilikan lahan petani di Desa Sukabakti ialah mayoritas lahan sewa yang seringkali dibantu oleh tenaga kerja buruh tani. Luas kepemilikan lahan seluas 0,5 sampai 4 hektar dengan lahan yang merupakan daerah sawah irigasi, sehingga lahan yang dimiliki relatif subur serta memiliki peluang dalam memperoleh keuntungan disebabkan panen yang berhasil. Dimana menurut Gatoet (2016), peluang memperoleh keuntungan yang disebabkan oleh panen yang berhasil akan lebih besar bila tanah garapan akan berhasil, lahan yang subur tersebut banyak dijumpai di daerah sawah terutama sawah irigasi.

Selama pandemi Covid-19 lahan tidak mengalami perubahan, petani terus melakukan kegiatan usahatani. Setara dengan harga 15 kwintal atau 1,5 ton gabah, petani harus membayar lahan sewa yang mereka sewa kepada pemilik lahan atau sebanyak $25 \%$ pembagian hasil sewa lahan kepada pemilik lahan.

\section{b. Tenaga Kerja}

Hasil penelitian, tedapat lima petani yang memberikan respon bahwa petani di Desa Sukabakti menggunakan tenaga kerja dikarenakan lahan yang digunakan cukup luas. Pemilihan buruh tani yang memiliki keterampilan dan pengalaman dalam membudidaya padi akan petani pilih. Tenaga kerja buruh tani akan diberikan pengupahan yang dibedakan menjadi dua sistem, pertama sistem upah harian tidak tetap yang dilakukan pada saat persemaian, penanaman dan melakukan panen. Pada hal ini buruh tani hanya bekerja satu hari dan kemudian dibayar secara langsung oleh petani. Kedua, sistem harian upah tetap yang dilakukan pada proses pengolahan lahan dan proses pemeliharaan saja. Hal ini dapat tenaga kerja lakukan lebih dari satu hari. 
Selama pandemi Covid-19, tenaga kerja buruh tani di Desa Sukabakti mengalami peningkatan yang disebabkan oleh banyaknya pekerja yang mengalami PHK dari pekerjaan sebelumnya, sehingga agar terus tetap terpenuhi kebutuhan hidupnya, masyarakat memilih bekerja sebagai buruh tani walaupun pengupahannya terbatas.

\section{c. Modal}

Berdasarkan hasil penelitian, terdapat lima petani yang memberikan respon bahwa dalam berusahatani petani menggunakan modal yang berasal dari hasil penjualan gabah padi mereka dari hasil panen sebelumnya dan disisihkan untuk penanaman berikutnya. Berdasarkan sifatnya modal petani menggunakan Labor Saving Capital yaitu dimana petani akan menggemat penggunaan tenaga kerja sehingga pengeluaran yang petani keluarkan pun sedikit dan mengurangi pinjaman untuk modal bertani.

Selama pandemi Covid-19, harga penjualan berupa gabah yang mereka jual kepada tengkulak atau pengepul menurun yang sebelumnya dihargai Rp5.000 per $\mathrm{kg}$ menjadi Rp4.000 per kg. Untuk itu, hadirnya Covid-19 secara tidak sengaja memberikan keringanan kepada petani dengan adanya bantuan yang berasal dari pemerintah berupa uang tunai dan sembako. Bantuan pemerintah berupa uang tunai tersebut digunakan petani di Desa Sukabakti untuk tambahan modal dalam berusaha tani serta pemenuhan kebutuhan sehari-hari keluarga mereka.

Selain modal yang berasal dari bantuan pemerintah, selama pandemi Covid-19 petani di Desa Sukabakti, memanfaatkan waktu kosongnya untuk melakukan pekerjaan sampingan sebagai pedagang untuk berjualan bubur ayam keliling menggunakan sepeda motor. Hasil penjualan tersebut sebagai tambahan modal pula untuk petani di Desa Sukabakti dalam menambah modal berusahatani dan pemenuhan kebutuhan lainnya.

\section{Proses Budidaya Tanaman Padi Selama Covid-19}

\section{a. Pengolahan Lahan}

Menurut hasil penelitian, selama pandemi Covid-19 pengolahan lahan tidak mengalami perubahan bahkan lima petani memberikan respon bahwa kegiatan budidaya khususnya dalam pengolahan lahan dilakukan seperti biasanya baik sebelum maupun adanya pandemi Covid-19. Pengolahan lahan dilakukan dengan menggunakan traktor, hal ini mereka gunakan untuk menghemat biaya produksi. Penggunaan traktor 


\section{ADAPTASI PERILAKU PETANI PADI DAERAH PINGGIRAN KOTA DI ERA COVID-19 \\ SERTA PENGARUHNYA TERHADAP USAHATANI \\ Yomitha Faradina, Yayat Sukayat}

dalam proses pengolahan lahan dapat menghemat biaya, dan dalam melakukan pekerjaan dapat lebih cepat serta efisien.

\section{b. Pembenihan}

Pembenihan menggunakan bibit dengan dua jenis varietas yaitu varietas MEKONGGA dan INPARI. Dalam proses ini pembenihan sedikit pengaruh selama pandemi Covid-19, yang disebabkan oleh benih yang petani miliki merupakan stok lama yang diperoleh dari sisa benih sebelumnya. Penggunaan stok benih ini menimbulkan banyak tanaman yang tidak tumbuh dengan baik. Penggunaan benih stok lama diakibatkan oleh harga benih yang cukup mahal dirasakan bagi petani di Desa Sukabakti, sehingga mereka mengharapkan adanya bantuan benih yang berasal dari pemerintah.

\section{c. Penanaman}

Berdasarkan hasil penelitian, selama pandemi Covid-19 proses penanaman petani mulai mengurangi penggunaan tenaga kerja buruh tani. Pada hal ini dilakukan karena keterbatasan modal serta untuk menghemat modal petani yang disebabkan selama Covid-19 kebutuhan mengalami peningkatan pada harga.

\section{d. Pemeliharaan Tanaman \\ 1. Pemupukan}

Berdasarkan hasil penelitian, tujuh petani memberikan respon bahwa pengaruh pandemi Covid-19 dalam proses budidaya tanaman padi sangat berpengaruh terhadap proses pemupukan. Pada saat ini pendistribusian pupuk bersubsidi mengalami gangguan yaitu terjadinya keterlambatan pada distribusi pupuk akibat pemberlakuan PSBB oleh pemerintah pusat. Sehingga selama pandemi Covid-19, petani hanya melakukan pemupukan sebanyak dua kali yaitu pada saat umur tanaman padi 15 hari dan 35 hari, setelah sebelumnya dilakukan sebanyak tiga kali yaitu 3 hari setelah tanam, 15 hari setelah tanam dan 35 hari setelah tanam. Pada hal ini membuat petani mengalami kesulitan untuk mendapatkan pupuk. Pendistribusian pupuk bersubsidi pun tidak semaksimal sebelum adanya pandemi, sehingga Covid-19 berpengaruh terhadap pendistribusian pupuk bersubsidi tersebut.

\section{Pengairan}

Dalam hasil penelitian, pengairan sawah di Desa Sukabakti baik sebelum maupun saat pandemi Covid-19, dilakukan dengan cara pengairan di atas tanah (irigasi) dengan sistem irigasi terus- 
menerus. Sistem irigasi terus-menerus diterapkan dengan memberikan air kepada tanaman padi mereka yang kemudian dibiarkan tergenang, dimulai saat setelah melakukan penanaman hingga beberapa hari mendekati hari panen. Penggunaan sistem ini dilakukan untuk menghemat biaya. Pada hal ini Covid-19 tidak mempengaruhi proses pengairan di Desa Sukabakti.

\section{e. Panen dan Pasca Panen}

Pada saat musim panen sebelumnya, petani di Desa Sukabakti mengalami penurunan hasil panen. Penurunan tersebut dilihat dari harga penjualan saat pandemic yaitu Rp4.000 per kg, yang sebelumnya dihargai Rp5.000 per kg. penurunan hasil panen bukan disebabkan oleh adanya pandemi, melainkan karena faktor lain yaitu banyaknya hama yang susah dikendalikan oleh petani di Desa Sukabakti seperti hama tikus sehingga padi tidak berbuah dengan maksimal.

Berdasarkan respon dari lima petani di Desa Sukabakti, hasil panen padi berupa gabah dihasilkan petani selama per enam bulan panen yaitu sebanyak 6 ton gabah per hektar. Selama pandemi Covid-19, mereka memprioritaskan hasil panen mereka untuk memenuhi kebutuhan pangan keluarga petani dahulu sebanyak 2-2,5 ton untuk dicukupkan selama menjelang hasil panen berikutnya. Kemudian sisa gabah tersebut dijual kepada tengkulak atau pengepul.

\section{Adaptasi Perilaku Petani Padi Daerah Pinggiran Kota Bekasi di Era Covid-19}

Berdasarkan hasil dari wawancara kepada lima petani padi, satu ketua kelompok tani dan satu kepala desa di Desa Sukabakti, Kecamatan Tambelang. Terdapat lima adaptasi yang dilakukan petani untuk bertahan hidup serta mempertahankan ketersediaan pangan di tengah-tengah masa pandemi Covid-19 diantaranya adalah:

\section{Pengurangan Tenaga Kerja Buruh Tani Menjadi Tenaga Kerja Keluarga dalam Berusahatani}

Keterbatasannya modal yang dimiliki petani selama pandemi Covid19, dimana pada saat ini pula harga kebutuhan semakin meningkat, sehingga mereka memprioritaskan kebutuhan sehari-hari dibandingkan dengan lainnya. Pengurangan tenaga kerja menjadi tenaga kerja keluarga dapat membantu petani dalam kegiatan berusahatani. Selama pandemi Covid-19 banyak keluarga baik anak-anak ataupun saudara petani yang mengalami PHK dari pekerjaan sebelumnya, sehingga dapat dimanfaatkan petani dalam membantunya 
untuk melakukan kegiatan seperti proses pemeliharaan tanaman dan saat panen. Penggunaan tenaga kerja buruh tani hanya digunakan saat proses persemaian dan menanaman karena dalam hal tersebut membutuhkan dan melibatkan banyak tenaga kerja.

$\begin{array}{cccc} & \text { Pengurangan } & \text { tenaga kerja } & \text { buruh } \\ \text { tani } & \text { selama } & \text { pandemi } & \text { hanya }\end{array}$ mempekerjakan 1-3 orang buruh tani, setelah sebelumnya mempekerjakan 5-6 orang buruh tani. Pengurangan ini selain dapat menghemat biaya atau modal petani juga sebagai bentuk petani dalam menaati himbauan dari pemerintah untuk menjaga jarak dan tidak melakukan kerumunan.

\section{Pengurangan Proporsi Penjualan Pada Gabah Padi}

Walaupun petani telah memaksimalkan stok hasil panen berupa gabah untuk dilakukan penjualan, namun petani selama pandemi Covid-19 lebih memprioritaskan untuk menyisihkan hasil panen usahatani padinya sebanyak 2-2,5 ton untuk kebutuhan pangan di rumah sebelum dijual kepada tengkulak. Setelah sebelumnya petani hanya menyisihkan gabah sebanyak 1 ton saja. Hal ini dilakukan serta cara petani untuk mengantisipasi kemungkinan gagalnya penanaman di kemudian hari serta memastikan persediaan beras terpenuhi dan aman, sehingga membuat petani dan keluarga lebih tenang selama masih tersedianya beras di rumah untuk bertahan hidup di tengah pandemi saat ini. Selama pandemi stok gabah pun petani simpan pada lumbung padi yang telah disediakan sebelumnya di rumah petani masing-masing, sehingga dirasakan petani cukup aman.

\section{Melakukan Pekerjaan Sampingan Sebagai Pedagang}

Berdagang merupakan pekerjaan sampingan yang dilakukan sebagian besar petani di Desa Sukabakti. Harga kebutuhan sehari-hari yang semakin meningkat dan cukup mahal, sehingga membuat petani melakukan pekerjaan berjualan bubur ayam keliling. Di samping harga kebutuhan yang semakin meningkat ditambah dengan hasil penjualan gabah yang juga menurun, namun tidak menurunkan semangat petani di Desa Sukabakti dalam bertahan hidup di saat pandemi ini. Hasil yang diperoleh petani ini mereka gunakan sebagai tambahan modal dalam memenuhi kebutuhan keluarganya serta tambahan modal untuk kegiatan berusahatani berikutnya.

\section{Pengurangan Pemberian Dosis Pupuk}

Pendistribusiaan pupuk bersubsidi yang mengalami keterlambatan bahkan 
ketersediaan pupuk pada agen pupuk bersubsidi yang tidak lagi tersedia, harga pupuk di pasaran pun cukup mahal. Hal ini menuntut petani untuk melakukan pengurangan pada pemberian dosis pupuk. Pandemi Covid-19 sangat mempengaruhi ketersediaannya pupuk bersubsidi bagi petani, di samping adanya pemberlakukan pembatasan sosial berskala besar (PSBB). Pemberian pupuk hanya dilakukan sebanyak dua kali, yaitu pada 15 hari setelah penanaman dan 35 hari setelah penanaman, yang saat sebelumnya pemberian pupuk dilakukan sebanyak tiga kali. Walaupun terjadinya pengurangan, petani tetap berharap agar hasil panen mereka memuaskan dan menghasilkan jumlah yang banyak serta berharap agar ketersediaan pupuk bersubsidi kembali seperti sebelumnya.

\section{Menerima Bantuan dari Pemerintah}

Telah terkonfirmasi bahwa selama pandemi Covid-19 petani serta masyarakan di Desa Sukabakti banyak yang telah menerima bantuan yang diberikan oleh pemerintah diantaranya bantuan yang berasal dari Pemerintah Kabupaten Bekasi berupa uang tunai dan sembako, serta bantuan dari Kementerian Sosial yang diberikan melalui kantor pos berupa uang tunai. Terkonfirmasi bahwa selama pandemi hampir $60 \%$ masyarakat desa termasuk petani telah terbantu dengan adanya bantuan dari pemerintah tersebut untuk mendukung dan sebagai tambahan modal petani dalam melakukan aktivitas dan kebutuhan sehari-hari.

\section{KESIMPULAN DAN SARAN}

\section{Kesimpulan}

Karakteristik petani padi di Desa Sukabakti, secara umun memiliki usia produktif yaitu pada kelompok umur 5059 tahun dengan tingkat pendidikan kategori terbanyak yaitu Sekolah Menengah Pertama (SMP). Tingkat pendidikan petani yang cukup rendah tetapi memiliki pengalaman yang tinggi yang petani peroleh dari kegiatankegiatan penyuluhan yang berasal dari Dinas Pertanian Kabupaten Bekasi. Lahan yang dimiliki petani cenderung merupakan lahan sewa dengan luas lahan pada skala luas yaitu lahan seluas 0,5-4 hektar.

Kondisi dengan segala kegiatan yang dibatasi dan umumya dirasakan oleh petani serta ditambah dengan adanya pandemi Covid-19 memberikan pengaruh dan dampak kepada petani serta keluarga petani terhadap perilaku dan aktivitas dalam berusahatani. Hal ini dikarenakan adanya pembatasan kegiatan seperti PSBB dan terbatasnya modal yang 


\section{ADAPTASI PERILAKU PETANI PADI DAERAH PINGGIRAN KOTA DI ERA COVID-19 \\ SERTA PENGARUHNYA TERHADAP USAHATANI \\ Yomitha Faradina, Yayat Sukayat}

dimiliki petani. Ukuran akan pengaruh atau dampaknya dengan pandemi Covid19 terhadap perilaku dan usahatani tergantung pada tingkat kepuasan serta kebutuhan masing-masing petani. Secara umum petani di Desa Sukabakti di tengah pandemi Covid-19 mengalami beberapa pengaruh, namun petani tetap merasa bersyukur akan ketersediaan pangan yang cukup yang mereka miliki. Selama pandemi Covid-19 harga kebutuhan mulai meningkat, namun tidak sebanding dengan pendapatan hasil panen petani yang sedang mengalami penurunan. Sehingga petani memilih untuk melakukan penahanan hasil panen untuk disimpan dahulu pada lumbung padi dan dilakukan penjualan saat harga gabah mengalami kenaikan yaitu pada saat sebelum panen raya datang. Pada hal ini menimbulkan tekanan baru bagi petani sehingga petani harus memprioritaskan ketersediaan pangan keluarga lebih dulu dibandingkan untuk di jual kepada tengkulak.

Adaptasi-adaptasi yang dilakukan petani padi pada masa pandemi Covid-19 untuk terus mempertahankan ketersediaan pangan pokok petani dan keluarga petani diantaranya adalah melakukan pengurangan tenaga kerja buruh tani menjadi tenaga kerja keluarga, melakukan pengurangan proporsi penjualan pada gabah padi, melakukan pekerjaan sampingan sebagai pedagang, melakukan pengurangan pemberian dosis pupuk dan menerima bantuan dari pemerintah.

\section{Saran}

Perlu adanya motivasi dan bantuan dari pemerintah terkait dengan pemasaran hasil panen padi, mengingat selama pandemi Covid-19 petani mengalami penurunan harga panen dan hanya dijual kepada tengkulak. Untuk itu pemerintah dapat melakukan kerjasama kepada bulog untuk membantu petani-petani kecil dalam memasarkan hasil panen, sehingga petani tidak mendapatkan harga yang terlalu rendah lagi.

Terkait distribusi pupuk bersubsidi yang mengalami keterlambatan akibat berlakunya PSBB, sehingga petani kesulitan dalam mendapatkan pupuk disamping harga pupuk yang cukup mahal dipasaran bagi petani. Untuk itu pemerintah dapat membantu petani dalam menyediakan pupuk bersubsidi dalam jumlah yang diperbanyak sehingga petani tidak lagi mengalami kesulitan dalam budidaya padi selama pandemi Covid-19.

Bantuan yang telah diberikan oleh pemerintah selama Pandemi Covid-19 hanya $60 \%$ masyarakat termasuk petani 
yang dapat merasakan bantuan tersebut.

Untuk itu pemerintah dapat melakukan pemberian bantuan tersebut secara bergantian.

\section{DAFTAR PUSTAKA}

Badan Pusat Statistik. (2018). Jawa Barat Dalam Angka tahun 2018. BPS.

Badan Pusat Statistik. (2013). Kabupaten Bekasi Dalam Angka tahun 2013. BPS.

Boer, R, et.al (2013). Rencana Aksi Mitigasi dan Adaptasi Perubahan Iklim Dalam Kerangka Pengelolaan Sumberdaya Air Di Das Citarum Di Kabupaten Bekasi. Bekasi: BPLH Kabupaten Bekasi.
FAO. 2020. Novel Coronavirus (COVID19). http://www.fao.org/2019ncov/en/.

Hardono, Gatoet, S. (2016). Analisis Perkembangan Sewa Menyewa Lahan Di Pedesaan Lampung. Lampung: Jurnal Agro Ekonomi.

Muttaqin, A.Z. (2008). Analisis Konsumsi Beras Rumah Tangga dan Kecukupan Beras Nasional Tahun 2002-2007. Tesis. Bogor: Institusi Pertanian Bogor.

Nurdiani, N. (2014). TEKNIK SAMPLING SNOWBALL. Comtech, 5(2), 1110-1118.

World Health Organization (2020). Coronavirus. Retrieved from World Health Organization: https://www.who.int/healthtopics/c oronavirus 